WPS2603

\title{
HOW THE QUALITY OF INSTITUTIONS AFFECTS TECHNOLOGICAL DEEPENING IN DEVELOPING COUNTRIES
}

\author{
George R. G. Clarke* \\ Development Research Group \\ The World Bank
}

George R. G. Clarke

Room MC2-608

The World Bank

1818 H Street NW

Washington, DC 20433.

gclarke@worldbank.org

Tel: $\quad 202-473-7454$

Fax: $202-522-1155$

\footnotetext{
* I would like to thank Philip Keefer for the institutional data. Responsibility for all errors, omissions, and opinions rests solely with the author. All findings, interpretations, and conclusions expressed in this paper are entirely those of the author and do not necessarily represent the views of the World Bank, its Executive Directors, or the countries they represent.
} 


\section{HOW THE QUALITY OF INSTITUTIONS AFFECTS TECHNOLOGICAL DEEPENING IN DEVELOPING COUNTRIES}

This paper assesses the effect of institutional quality on $R \& D$ expenditures in developing countries. The paper finds that the risk of expropriation and the rule of law are correlated with $R \& D$ expenditures. Since both institutional variables increase as institutional quality improves (i.e., as risk of expropriation decreases and rule of law improves), this suggests that stronger institutions encourage greater $R \& D$ expenditures. The result for the risk of expropriation is more highly significant and far more robust than the result for the 'rule of law'. Although R\&D is not the primary way that developing countries gain access to technology, this result is interesting for at least two reasons. First, R\&D might encourage technological deepening better than other methods that developing countries use to gain access to technology (e.g., through FDI or capital goods imports). Second, past work has shown that another important way that developing countries gain access to technology, through FDI, is also positively correlated with institutional quality (i.e., as institutional quality improves, FDI increases). 


\section{INTRODUCTION}

Acquiring new technology is not simply a matter of purchasing new machinery or product designs. Learning how to use and adapt technologies to local circumstances and imitating existing products and processes takes considerable effort. ${ }^{1}$ In a study of U.S. firms, Mansfield et al. (1981) find that imitating new products is especially costly when imitating firms have less 'know-how' than the innovating firm has. Enterprises in developing countries, trying to imitate technologies or ideas imported from developed countries, are likely to suffer from this kind of knowledge gap. In addition, the large institutional and economic differences between developed and developing countries mean that, in many cases, enterprises will benefit from adapting, and improving, technologies to local circumstances rather than imitating products and processes directly. Some ways of acquiring technology, e.g., investment in local research and development (R\&D) or licensing, might increase an enterprise's ability to adapt and improve technologies better than others, e.g., Foreign Direct Investment (FDI). Therefore, even though R\&D is probably not the primary way that enterprises in developing countries acquire technologies, factors that affect local $R \& D$ expenditures might be of interest, if $R \& D$ encourages technological deepening. This paper studies whether one particular factor, institutional quality, affects $R \& D$ expenditures in developing countries.

In general, since returns to R\&D will often be spread over several years, firms will need significant periods to recover expenditures. If firms and individuals are unsure about the institutional environment, they might be unwilling to commit the necessary funds to R\&D. Although this is true for all medium and long-term investment, because 'ideas' are non-rivalous, they are probably more at risk from expropriation than other forms of investment. Keefer and Knack (1997) write:

\footnotetext{
${ }^{1}$ Several authors, including Bell and Pavitt (1986), make this point in reference to developing countries. In a study of U.S. firms, Mansfield et al. (1981) finds that, on average, it cost imitating firms $65 \%$ of the cost of innovation to imitate new products. In one seventh of the cases, imitation costs were at least as high as innovation costs. Mansfield et al (1981) suggest 'this was not due to any superiority of the imitative product over the innovation. Instead, in a substantial percentage of these cases, it was due to the innovator's having a technological edge over its rivals in the relevant field. They also found that although patents increased the cost of imitation, the median estimated increase was only $11 \%$.
} 
"More secure property right and credible policy regimes increase the incentives of entrepreneurs to adopt those techniques that maximize longrun profits. Firms make less efficient adjustments and continue to use obsolescent technology if those policies are not credible, or if optimal firm adjustments leave them more vulnerable to expropriation." (p. 591)

This paper finds that expenditures on $R \& D$ tend to be lower in countries where the risk of expropriation is higher and the rule of law is weaker. This confirms the importance of institutional quality on technological innovation and is consistent with the cross-country analysis in Knack and Keefer (1995) that finds that long-run growth is significantly correlated with similar measures of institutional quality.

Although FDI, rather than R\&D is probably the primary way that enterprises in developing countries acquire technology, this study adds to existing work in several ways. $^{2}$ First, expenditures on R\&D are one way that developing countries increase technological depth. ${ }^{3}$ Other methods of acquiring technology, such as FDI, might be less successful in this regard. Second, it complements other studies (e.g., Gastanaga et al., 1998, and Lee and Mansfield, 1996) that have shown that foreign direct investment (FDI) is also positively correlated with institutional quality. ${ }^{4}$

The paper is organized as follows. The next section discusses the data used in the analysis. Section 3 describes the empirical results. Section 4 conducts some sensitivity analysis and Section 5 concludes.

\section{FACTORS AFFECTING R\&D EXPENDITURES}

To study the cross-country correlation between expenditures on research and development $(\mathrm{R} \& \mathrm{D})$ in developing countries and measures of institutional development,

\footnotetext{
2 See, for example, World Bank (1998).

3 Although, expenditures on R\&D are an input to technological deepening (rather than a measure of output), it is probably better measured than output variables such as patents, especially in countries with weak protection of intellectual property.

${ }^{4}$ Wei (1999) shows that foreign direct investment is negatively correlated with corruption, which tends to be negatively correlated with measures of institutional quality (see Knack and Keefer, 1995).
} 
we assemble a panel of data from low and middle-income countries. ${ }^{5}$ Panel data are well suited to exploring the relationship between $\mathrm{R} \& \mathrm{D}$ expenditures and other economic variables for several reasons. Including fixed effects will help to control for omitted country characteristics (that are roughly constant over time) that might be correlated with both $\mathrm{R} \& \mathrm{D}$ expenditures and the independent variables. This might also help to partially control for different measurement methods used for R\&D in different sample countries. ${ }^{6}$ In addition to the institutional variables, additional variables are included to control for other possible factors that might affect R\&D Expenditures. Means, standard deviations and sources of data are shown in Table 1.

\section{Institutional Development.}

The variables we use for institutional quality are 'risk of expropriation' and 'rule of law', two measures used by Knack and Keefer (1995) to proxy for the security of property and contract rights. These measures are produced by the International Country Risk Guide (ICRG), a private international investment risk service. The first indicator measures the risk of confiscation or forced nationalization, and the second measures the degree to which established institutions make and enforce laws and adjudicate disputes. For both measures, higher values indicate stronger institutions. ${ }^{7}$ For example, high values for 'risk of expropriation' indicate that nationalization or confiscation is less, not more, likely. In this study, 'risk of expropriation' is intended as a general measure of the security of property rights. Governments that are more willing to confiscate property are probably also less likely to respect private property rights in disputes between private parties. These measures are highly correlated with other measures of weak property

\footnotetext{
5 Middle-income countries have per capita income (for that particular year) between US\$500 and $\$ 6000$ in constant 1987 dollars and low-income countries have per capita income (for that particular year) of less than US\$500. These cutoff points are the points used in the 1989 World Development Report (World Bank, 1989).

6

6 Although the dependent variable might be badly measured, it is not clear that this will have a large impact on results. Unlike measurement error in independent variables, measurement error in the dependent variable does not bias parameter estimates, unless the measurement error is systematically correlated with the independent variables. That is, the measurement error can be absorbed into the disturbance term for the regression.

See Knack and Keefer (1995, p.225-226) for more complete descriptions of these variables.
} 
rights, such as the level of corruption. ${ }^{8}$ Keefer and Knack (1995) note that since private investors are willing to pay substantial amounts for these indices, they presumably contain some information.

\section{Per Capita Income}

World Bank (1998) notes that R\&D expenditures in low and middle-income countries tend to be lower than expenditures in industrial countries (in both absolute terms and relative to GDP). For example, in this sample, mean R\&D expenditures in high-income industrial countries in 1994 was $1.8 \%$ of GDP compared to $0.8 \%$ in low and middle-income countries. ${ }^{9}$ This could be because other explanatory variable that vary systematically with income also affect R\&D expenditures. For example, wealthier countries tend to have higher levels of human capital, which is presumably an important input for R\&D, and stronger institutions, which might affect individuals' or firms' willingness to invest in long-term projects (such as R\&D investments). ${ }^{10}$ Although we include measures of institutional quality and human capital in the base regression, per capita income might capture other effects and help control for omitted variables. Per capita income squared is also included in the base regression to allow for a possible nonlinear effect.

\section{Human capital.}

Human capital and the educational ability of the populace are likely to affect technological capability and R\&D expenditures. As Romer (1992) points out, although that there is a distinction between the pure private good, human capital, and the nonrivalous good 'ideas', it is clear that the two are closely linked. A country's endowment of human capital might affect $R \& D$ expenditures in several ways. First, countries with

\footnotetext{
8 See Knack and Keefer (1995, footnote 9). The link between corruption and growth is discussed in Mauro (1995).

9 This is the last sample year for which a large number of observations is available. The high-income industrial countries are Australia, Austria, Canada, Spain, France, Italy, Japan, the Netherlands, Singapore and the United States. The low and middle-income countries are Argentina, Bulgaria, Brazil, Belarus, Chile, China, Czech Republic, Egypt, Hungary, India, Iran, Korea, Latvia, Lithuania, Moldova, Poland, Russia, Slovak Republic and Turkey.

10

For the correlation between institutional quality and per capita GDP, see Keefer and Knack (1997), Table 1.
} 
high levels of human capital might have a comparative advantage in $R \& D$ - it is generally accepted that $R \& D$ uses highly trained individuals, such as scientists and engineers, intensively. Second, a large share of R\&D activity is performed in universities and, therefore, countries that invest heavily in tertiary education might have higher R\&D expenditures. ${ }^{11}$ Finally, studies of R\&D in the United States have found that geographical proximity is important for local innovation. ${ }^{12}$ It is plausible that proximity might also be important for innovation in middle-income countries, especially considering that the poor infrastructure might make long-distance communication problematic in developing countries. Therefore, expenditures on universities might also encourage $R \& D$ in local enterprises.

\section{Development of Capital Markets.}

Access to capital might also effect private enterprises' ability to finance research and development. This has been a practical concern for policy-makers. World Bank (1995), which summarizes World Bank experience with loans for industrial technological development, notes that five of the six projects surveyed included components that provided finance for technological activities. Although financial intermediaries might directly finance only a small portion of innovative activity, King and Levine (1993, p. 517) note that they can increase the returns to innovative activity by helping entrepreneurs bring successful ideas to the market. Well functioning financial markets will, therefore, increase the return to research and development even if they do not directly finance investment in R\&D. In this paper, we use one of the main variables from King and Levine (1993) as a proxy for financial market development - bank credit to private enterprises as a share of GDP (p. 529). Financial systems that allocate large portions of bank credit to private enterprises - rather than to the government or to public

\footnotetext{
11 Several studies (e.g., Dahlman et al., 1987) advise that government funded basic research might not be justified in developing countries. They suggest "research institutes can get on tracks that do little for a country's productivity and efficiency. There is, moreover, much more scope in developing countries for applied rather than basic research..."(p.774). In contrast, other studies (e.g., Bell and Pavitt, 1993) suggest that "the main economic benefit of basic research is not published information, but a supply of scientists and engineers with problem solving skills, familiarity with research methodologies and instrumentation, and membership in informal and international networks of professional peers. (p. 271)
} 
enterprises - are likely to have more experience in evaluating potentially successful innovations. This variable, which reflects the development of the banking sector, seems to capture the concept that we are interested in quite well.

\section{Openness to Trade and Investment}

In addition to the other economic variables, we also include several measures of openness to foreign trade and investment. Dahlman (1994) notes that access to foreign capital, either through foreign investment or through capital goods imports, might be an important way of acquiring technology in developing countries. The effect on $R \& D$ expenditures is, therefore, ambiguous since openness may serve as a substitute for domestic innovation. In addition, FDI might crowd out domestic R\&D if FDI uses similar inputs to $\mathrm{R} \& \mathrm{D}$, and these inputs take time to build (e.g., experienced engineers and scientists). The degree of substitution is of interest, because although openness might be an effective way of acquiring technology, it might be a less effective way to increase technological depth. For example, World Bank (1995) suggests:

"A heavy reliance on foreign direct investment can be an extremely effective method of transferring operational know-how of new technologies, and can have numerous beneficial externalities. It may not, however, be the best way to promote technological deepening

The measures of openness to trade that we use are imports and exports as share of GDP and the black market premium. The first measure is a direct measure of the importance of imports and exports. The inclusion of fixed effects makes this measure somewhat similar to measures of structural adjusted trade intensity (see Pritchett, 1996). Since many factors that affect trade intensity (e.g., population, size of the economy, and natural resource endowments) do not change greatly over short periods, these effects will be partially controlled for by the inclusion of country dummies. That is, once fixed effects are included in the regression, this variable measures the deviation from the (country-specific) mean level of imports and exports. The second measure of trade

\footnotetext{
12 See Jaffe (1989) and Audretsch and Feldman (1996). Audretsch and Stephan (1996) finds although that geographical proximity appears to matter, it is less important in establishing formal ties than informal ties.
} 
policy is the black market exchange rate premium. However, although studies have used this as a measure of trade policy, Pritchett (1996, p. 314) notes that it has also been used as a measure of macroeconomic stability, economic freedom and exchange rate overvaluation. The final measure of openness is openness to investment, rather than trade. The indicator used is net incoming FDI.

\section{Government and Defense Expenditures}

Government expenditures might affect R\&D expenditures in several ways. First, governments directly fund significant amounts of research in universities, research laboratories and even private enterprises, in both developed and in developing countries. Further, if geographical spillovers are important, then government-funded research might also increase R\&D expenditures by local firms. For these reasons, if total government expenditures are correlated with government expenditures on $R \& D$, we might expect government expenditures to be correlated with $R \& D$ expenditures. However, if government $\mathrm{R} \& \mathrm{D}$ expenditures displace private expenditures - either by using scarce human and physical resources or because private enterprises use government research to replace their own efforts - then it might have little effect on total R\&D. Further, high taxes might discourage private $R \& D$, especially if enterprises are unable to depreciate R\&D investment in the same way as other investment. This could lead to a negative correlation between government expenditures and R\&D expenditures. In addition to total government expenditure, we also include defense expenditures in the base regression. In many countries, significant amounts of government sponsored R\&D are, directly or indirectly, for defense-related purposes. ${ }^{13}$ For this reason, we might expect defense expenditures to be significantly correlated with R\&D expenditures.

\footnotetext{
13 Ram (1995) notes that empirical work on defense expenditures and growth suggests that defense expenditures do not appear robustly correlated with economic growth. He suggests that this might be due to offsetting effects from externalities (perhaps due to the effect of defense expenditures on human capital formation or technological progress) and resource diversion.
} 


\section{EMPIRICAL RESULTS}

The data used in the empirical section are annual data from between 1983 and 1994. Since multiple observations are available over this period, we essentially have an (unbalanced) panel. Fixed country and time effects are included in all regressions, in addition to the other independent variables discussed above. This, essentially, means that all variables are demeaned using individual country means. Consequently, there are no 'high' or 'low' investment countries in the sample. Including fixed effects has several distinct advantages over simple ordinary least squares:

1. Including fixed effects in the regression helps to control for omitted variables that are (more or less) constant over the period. For example, some countries might have a tradition of engaging in scientific research or a large stock of human capital specialized in R\&D.

2. It is possible that the definition of $R \& D$ expenditures varies systematically across countries. However, if the definitions used by individual countries are (more or less) constant over time, then fixed effects might partially control for these differences.

Another concern is the direction of causality for some of the economic variables and, to a lesser extent, the institutional variables. For example, differences in R\&D expenditures might alter the pattern of imports and exports in the medium or long-term. However, R\&D expenditures are likely to take several years to influence economic and institutional variables, and, therefore, this might not be a major concern. We lag the economic and institutional variables by one year to further minimize this risk. Given the delayed influence of $R \& D$ expenditures on the other variables, the inclusion of fixed effects might be especially helpful. That is, once fixed effects are included in the regression we are considering, for example, whether R\&D expenditures were increasing (relative to the country-specific mean) in those countries where institutional quality was improving (relative to the country-specific mean), not whether R\&D expenditures are high in those countries with strong institutions. A similar argument applies to the economic variables. 
Table 3 shows the results from fixed effects regressions for middle and lowincome countries. Column (1) shows the results from a regression that includes all of the economic and institutional variables. When both rule of law and risk of expropriation are included in the regression, both variables are statistically significant at conventional 5\% or $10 \%$ levels. However, the coefficient on the risk of expropriation tends to be more highly significant throughout the empirical analysis. The positive coefficients are consistent with the hypothesis that greater protection of property rights and stronger institutions are correlated with greater expenditure on R\&D. Given the high correlation between these two institutional variables ( 0.76 in the sample of middle and low-income countries), there might be a problem with multicollinearity. Columns (3) and (5) show similar regressions with the risk of expropriation and the rule of law omitted. The results in column (3) are almost identical to the results in column (1). Omitting the risk of expropriation variable from the regression increases neither the magnitude nor the significance of the rule of law variable (see column 5).

Several of the economic control variables are also statistically significant. Higher per capita GDP is correlated with higher R\&D expenditures after controlling for the other institutional and economic variables. This positive, and statistically significant, correlation remains throughout the analysis. Consistent with the hypothesis that human capital is positively correlated with $\mathrm{R} \& \mathrm{D}$ expenditures, the primary enrollment rate is positively correlated with $R \& D$ expenditures. However, the tertiary enrollment rate is statistically insignificant and the observed correlation between the primary enrollment rate and $R \& D$ expenditures is not highly robust. Once the statistically insignificant control variables are dropped, the coefficient on the primary enrollment rate becomes insignificant. Claims on the private sector by deposit money banks and the central bank is not significantly correlated with $\mathrm{R} \& \mathrm{D}$ expenditures in any of the regressions for low and middle-income countries. One of the measures of openness, incoming FDI, is significantly negatively correlated with $R \& D$ expenditures. This result appears quite strong - it is robust to changes in the sample (see Table 3, Columns 7-12) and to changes in the other control variables (see Table 3, Columns 2,4 and 6). 
The measures of openness to trade - exports and imports as a percentage of GDP and the black market premium are not significantly correlated with the dependent variable. This does not seem to be due to multicollinearity, since the two variables are also jointly insignificant at a $10 \%$ level. ${ }^{14}$ Finally, government expenditures are negatively correlated with R\&D expenditures (at a $10 \%$ level), while defense expenditures are positively correlated with $R \& D$ expenditures. However, a better measure of the correlation between defense expenditures and $R \& D$ expenditures might be the sum of the two coefficients since most defense expenditures are government funded. The sum is positive but statistically insignificant in the model specifications in columns (1)-(3).

The fixed effects are highly significant in all regressions in Table 3 . We reject the (joint) null hypothesis that the state dummies are all equal and that the time dummies are all zero at less than a $1 \%$ level for all regressions. The two hypotheses are also rejected separately at similar levels of significance. This strongly suggests that including state and time dummies in the regression is appropriate.

In columns (7) and (8), we present results from similar regressions using a sample that includes developed countries in addition to the developing countries. This more than doubles the total number of observations and nearly doubles the number of countries. The "risk of expropriation" remains significantly, and positively, correlated with R\&D expenditures. In addition, per capita income remains significantly and positively correlated with R\&D expenditures and the coefficient on (incoming) foreign direct investment remains significant and negative. The trade variables remain statistically insignificant (singly and jointly) at conventional significance levels. The only noticeable changes are that the coefficient on the tertiary enrollment rate becomes statistically significant and positive, the coefficient on the claims on private sector by deposit money banks and the central bank becomes statistically significant, while the coefficient on government expenditures becomes statistically insignificant and positive. This final

\footnotetext{
${ }^{14}$ Further, these two measures are not significantly correlated with each other. The low correlation between different measures of openness is discussed in Pritchett (1996).
} 
result means that the sum of the coefficients on government expenditures and defense expenditures is positive and statistically significant. Overall, the results are similar to the results for the smaller sample of low and middle-income countries.

In columns (9) and (10), we drop low-income countries (less than $\$ 600$ per capita in 1987 US\$). This reduces the number of observations and the number of countries slightly. However, the results are broadly similar to the results for the two other subsamples: the coefficient on the risk of expropriation remains highly significant, as does the coefficient on openness to foreign direct investment. Further, the coefficient on the two other openness variables remains statistically insignificant (jointly and singly). Finally, columns (11) and (12) drop the transition economies of Europe and Central Asia from the regression. This reduces the degrees of freedom and the number of countries more significantly. Given the low number of observations and countries that remain after dropping these countries, it is probably reasonable to treat these results with some level of caution. The significance level of the coefficient on the risk of expropriation remains negative but becomes smaller in absolute value and falls to a $10 \%$ significance level. The coefficient on the openness to foreign direct investment remains similar in terms of statistical significance and sign, although it does become smaller in absolute value. The coefficients on government expenditures and defense expenditures also become statistically insignificant at conventional levels. The other significant change is that once these observations are dropped for the regression, the coefficients on the two openness variables become negative and statistically significant at, at least, a 10\% level. This suggests that, for these countries, increased openness is correlated with lower R\&D expenditures. However, as noted above, these results should be treated with caution considering the small number of observations and countries in this sample.

In summary, several results from this section appear to be robust across different samples and different sets of control variables. The institutional variables are positively correlated with R\&D expenditures. Since both variables increase as institutional quality improves (i.e., as risk of expropriation decreases and rule of law improves) this suggests that stronger institutions are, in general, correlated with greater $R \& D$ expenditures. The result for the risk of expropriation is more highly significant and far more robust. 
Second, after controlling for the other economic and institutional variables, per capita income remains positively correlated with $R \& D$ expenditures. Third, two of the measures of openness are, in general, uncorrelated with $R \& D$ expenditures while the third, incoming FDI is negatively correlated with R\&D expenditures. The last result appears highly robust to different model specifications. Finally, government expenditures tend to the negatively correlated with $R \& D$ expenditures, while defense expenditures tend to be positively correlated with $R \& D$ expenditures. The sum of the two coefficients, which would be the coefficient on government-funded defense expenditures, is statistically insignificant in some, but not all, specifications.

\section{Sensitivity ANALYSis.}

One reasonable concern is that the results presented in the previous section might prove to be highly sensitive to the inclusion, or exclusion, of other variables - a problem in many areas of applied economics. To counter this, in the context of cross-country growth regressions, Levine and Renelt (1992) propose a test based upon Leamer's (1983)

extreme bounds analysis (EBA) ${ }^{15}$ Essentially, they propose running the regression with many different combinations of variables and noting whether the coefficient on the variable of interest is affected by the choice of other regressors. Levine and Renelt (1992) divide the independent regressors into three distinct groups: the I, or included variables; the $\mathrm{M}$ variable, the variable of interest; and $\mathrm{Z}$ variables which are only included in some specifications of the model. ${ }^{16}$

$$
R \& D=\beta_{i} I+\beta_{m} M+\beta_{z} Z+u
$$

The I variables are included in all specifications of the model, as is the M variable, the variable of interest. The $\mathrm{Z}$ variables, a large pool of variables that might affect aggregate $R \& D$ expenditures, are systematically added and removed from the base

\footnotetext{
15 See McAleer et al. (1985) and Sala-i-Martin (1996) for critiques of this methodology. For a response to McAleer et al (1985) see Leamer (1985).

16 See Levine and Renelt (1992) for a more complete discussion of this procedure.
} 
regression until all possible combinations of $\mathrm{Z}$ variables have been included. After each iteration, the researcher notes the coefficient on the $M$ variable, $\beta_{\mathrm{m}}$, and its standard error. The highest and lowest values of $\beta_{\mathrm{m}}$ that would be accepted at a given significance level are then computed for each set of $\mathrm{Z}$ variables and compared. The $\beta_{\mathrm{m}}$ with the highest acceptable $\beta$ associated with it becomes the upper extreme bound and the $\beta_{\mathrm{m}}$ with the lowest acceptable $\beta$ associated with it becomes the lower extreme bound. If the extreme bounds have the same sign (and are both significant) Levine and Renelt (1992) call the relationship between the dependent variable and the variable of interest 'robust'. If this is not true, they label the relation as 'fragile'.

There are several problems with this procedure. First, omitting relevant variables might bias results and lead to incorrect inference, while including irrelevant variables might increases the standard errors on parameter estimates. For these reasons, labeling a coefficient as 'fragile' does not mean that the independent variable is not correlated with dependent variable. In response to Levine and Renelt's (1992) finding that few variables are robustly correlated with economic growth, Sala-i-Martin (1997) suggests:

"Another explanation is that the test is too strong for any variable to pass: if the distribution of $\left[\beta_{\mathrm{m}}\right]$ has some positive and some negative support, then one is bound to find one regression for which the estimated coefficient changes signs if enough regressions are run. Thus, giving the label of non-robust to all variables is all but guaranteed." (p. 179).

However, this procedure might convince readers that results are not highly sensitive to changes in the conditioning information sets. For this reason, we summarize the results slightly differently from Levine and Renelt (1992). We call a variable "robust" if the point estimate remains significant (and the same sign) in all regressions. If the point estimates remain the same sign in all regressions, we label the result as "point estimates positive (or negative)". If the point estimate switches sign, then we label the estimate as 'fragile'. As noted above, fragile does not necessarily imply that the variable is not related to $\mathrm{R} \& \mathrm{D}$ expenditures. However, these results might be treated more cautiously than results labeled 'robust'. 
The variables of interest ( $\mathrm{M}$ variables) that we test for robustness are the variables that are included in reduced regression (i.e., variables included in the regression shown in column 4 of Table 3). The other five variables are included in all model specifications (i.e., they are the I, or included, variables). The other variables in the expanded regression, which are not robust since they are insignificant in that regression (i.e., in column 1 of Table 3 ), are the $\mathrm{Z}$ variables. ${ }^{17}$ Table 2 summarizes the results for this the $\mathrm{M}$ variables.

These results broadly confirm the results from the previous section. Three of the variables, the risk of expropriation, per capita income and incoming foreign direct investment are robustly correlated with $R \& D$ expenditures. The coefficient on government expenditures and defense expenditures remain the same sign in all regressions but become statistically insignificant in some model specifications. The final variable, the primary enrollment rate, is less robust - in some model specifications, the coefficient actually switches sign.

\section{Conclusion}

In summary:

1. After controlling for other factors that might affect expenditures on research and development in low and middle-income countries, per capita GDP remains robustly correlated with R\&D expenditures (as a percentage of GDP). This might be because of other omitted factors that differ systematically between countries or because lower income countries tend to rely less on R\&D for technological innovation than higherincome countries even among low and middle-income countries.

2. In general, countries with weaker institutions tend to have lower $R \& D$ expenditures than countries with stronger institutions. This result appears quite robust across different samples and to different sets of control variables.

\footnotetext{
17 These are per capita GDP squared, tertiary enrollment rate, rule of law, claims on the private sector by the central bank and deposit money banks, openness to trades and the black market premium.
} 
3. Another robust result is the negative correlation between $R \& D$ expenditures and foreign direct investment. This result seemed robust across different samples and to different sets of conditioning variables. Since FDI is also negatively correlated with institutional quality (Gastanaga et al., 1998), this might partially offset the effect of institutional quality on $\mathrm{R} \& \mathrm{D}$ expenditures.

4. Government expenditures were negatively correlated with $R \& D$ expenditures in many specifications of the model. Given the large role that the government often plays in funding research in developing countries this result is somewhat surprising. Defense expenditures are often positively correlated with R\&D expenditures. Since defense expenditures are generally government-funded, the coefficient on (government-funded) research is the sum of the coefficients on government expenditures and defense expenditures. This sum is zero in many model specifications, suggesting that the two effects appear to cancel out.

5. Measures of openness to trade were not correlated with R\&D expenditures in most model specifications.

Although other ways of acquiring new technologies (e.g., FDI) are probably more important than expenditures on $R \& D$, the results are suggestive for several reasons. First, R\&D expenditures might be an important way to promote technological deepening. Several studies have noted that acquiring technology through, for example, the purchase of capital goods does not give enterprises the ability to adapt that technology to local circumstances or allow them to generate incremental improvements. ${ }^{18}$ If technological deepening is important, these results are of immediate interest. Second, the positive correlation between institutional quality and $\mathrm{R} \& \mathrm{D}$ expenditures is of special interest given that other studies have found that institutional quality is also positively correlated with foreign direct investment, another way of acquiring technological expertise. For example, Gastanaga et al (1998) found that foreign direct investment was lower in countries with greater bureaucratic delay and higher nationalization risk and Wei (1999)

\footnotetext{
18 See, for example, Ball and Pavitt's (1992) discussion of production capacity and technological capabilities or Romer's (1992) discussion of 'using ideas vs. producing ideas'.
} 
found that corruption discourages foreign direct investment. Similarly, Lee and Mansfield (1996) found that perceptions concerning the strength of intellectual property rights affected both the volume and the composition of U.S. foreign direct investment. It seems reasonable that institutional quality will also affect other methods of acquiring technology, such as through licensing. ${ }^{19}$

It is unlikely that the effect of institutional quality on foreign direct investment drives the correlation between institutional quality and $R \& D$ expenditures. First, we control for the effect of FDI in the empirical analysis. Second, Patel and Pavitt (1991) note that, even among OECD countries, large firms tend to concentrate $\mathrm{R} \& \mathrm{D}$ expenditures in their home countries. It is even less likely that investors would concentrate R\&D intensive activities in developing countries, since developing countries probably do not have a comparative advantage in these areas. In summary, institutional quality seems to affect the level of $R \& D$ expenditures in developing countries directly. Since, institutional quality also affects other method of acquiring technology, such as FDI, poor institutional quality is likely to slow technological development. This result is consistent with the observation in Knack and Keefer (1995) that the coefficients on institutional variables remained significant after controlling for investment - they suggest (p. 219) this is because the threat of expropriation discourage dynamic gains from innovation.

The negative correlation between FDI and R\&D expenditures is also robust across many different model specifications. One possible reason for the observed correlation is that FDI is a substitute for R\&D - enterprises that are unable to obtain technology through foreign direct investment are forced to invest in $R \& D$. However, another possibility is that FDI crowds out some R\&D by consuming scarce resources (such as trained engineers) that take time to build.

Although the negative correlation between FDI and own investment in R\&D might be worrying, it confirms, in a cross-country setting, results from case studies that

\footnotetext{
19 Dahlman (1994) discusses different ways that developing countries might acquire technological expertise.
} 
have suggested that FDI does not lead directly to increased domestic innovation and technological deepening. ${ }^{20}$ Pack and Saggi (1997, p. 89) note that the observed preference that Japan and Korea demonstrated for licensing over direct investment might have been because they believed that the spillover from licensing was greater than the spillover from FDI and that this would allow "their firms to more quickly move towards innovative R\&D”. In addition, based upon case studies of World Bank loans for industrial technology projects, World Bank (1995) suggests:

"The deepening of industrial technological capability may also need interventions in trade and technology regime that promote local research activity. Exposure to international competition and technology flows by itself may not - as witnessed in Mexico and Korea - be sufficient for the promotion of technological effort."

Although the results suggest that other policy interventions might be necessary to encourage deepening (especially if a heavy reliance on FDI discourages domestic innovation), they do not justify steps to reduce FDI. For example, World Bank (1995) suggests that India's isolation from foreign technology led to distortions that outweighed the benefits of technological deepening, even in terms of innovative capability.

\footnotetext{
20 See, for example, Romer's (1992) discussion of Mauritius and Taiwan or Dahlman's (1994) discussion of newly industrialized economies in East Asia. Dahlman (1994) notes, comparing Korea and Taiwan with Hong Kong and Singapore that, of these countries, the ones that are most dependent on FDI (Singapore and Hong Kong) also invest less in their own R\&D.
} 


\section{REFERENCES}

Audretsch, David B. and Maryann P. Feldman. 1996. "R\&D spillovers and the geography of innovation and production." American Economic Review, 86, 630640 .

Audretsch, David B. and Paula E. Stephan. 1996. "Company-scientist locational links: The case of biotechnology." American Economic Review, 86, 641-652.

Bell, Martin and Keith Pavitt. 1992. "Accumulating technological capability in developing countries." Proceedings of the World Bank Annual Conference on Development, 1992, 257-281.

Dahlman, Carl J. 1994. "Technology strategy in East Asian developing economies." Journal of Asian Economics, 5 (4), 541-572.

Dahlman, Carl J., Bruce Ross-Larson and Larry E. Westphal. 1987. “Managing technological development: Lessons from the newly industrializing countries." World Development, 15, 759-775.

Gastanaga, Victor M., Jeffrey B. Nugent and Bistra Pashamova. 1998. "Host country reforms and FDI inflows: How much difference do they make?" World Development, 26 (7), 1299-1314.

Jaffe, Adam. 1989. "Real effects of academic research." American Economic Review, 79, 957-970.

Keefer, Philip and Stephen Knack. 1997. "Why don't poor countries catch up? A crossnational test of an institutional explanation." Economic Inquiry, 35, 590-602.

Knack, Stephen and Philip Keefer. 1995. "Institutions and economic performance; Cross-country tests using alternative institutional measures." Economics and Politics, 7, 207-227.

Leamer, Edward E. 1983. "Let's take the con out of econometrics." American Economic Review, 73, 31-43.

Leamer, Edward E. 1985. "Sensitivity analyses would help." American Economic Review, 75, 308-313.

Lee, Jeong-Yeon and Edwin Mansfield. 1996. "Intellectual property protection and U.S. foreign direct investment." Review of Economics and Statistics, 78, 181-186.

Levine, Ross and David Renelt. 1992. "A sensitivity analysis of cross-country growth regressions." American Economic Review, 82, 943-963. 
Mansfield, Edwin, Mark Schwartz and Samuel Wagner. 1981. "Imitation costs and patents: An empirical study.” Economic Journal, 91, 907-918.

Mauro, Paolo. 1995. "Corruption and growth." Quarterly Journal of Economics, 110, 681-712.

McAleer, Michael; Adrian Pagan and Paul A. Volker. 1985. "What will take the con out of econometrics?" American Economic Review, 75, 293-307.

Pack, Howard and Kamal Saggi. 1997. "Inflows of foreign technology and indigenous technological development." Review of Development Economics, 1 (1), 81-98.

Patel, Pari and Keith Pavitt. 1991. "Large firms in the production of the world's technology: An important case of 'non-globalization'." Journal of International Business Studies 22 (1), 1-21.

Pritchett, Lant. 1996. "Measuring outward orientation in LDCs: Can it be done?" Journal of Development Economics, 49, 307-335.

Ram, Rati. 1995. "Defense expenditures and economic growth." In K. Hartley and T. Sandler. Handbook of Defense Economics Vol. 1. Elsevier Science.

Romer, Paul. 1992. "Two strategies for economic development: Using ideas and producing ideas." Proceedings of the World Bank Annual Conference on Development, 1992, 62-91.

Romer, Paul. 1993. "Idea gaps and object gaps in economic development." Journal of Monetary Economics, 32, 543-573.

Sala-i-Martin, Xavier. 1997. "I just ran two million regression." American Economic Review Papers and Proceedings, 87, 178-183.

Wei, Shang-Jin, 1999. "How taxing is corruption on international investors?" Review of Economics and Statistics 81 (4), 1-12.

World Bank. 1989. World Development Report 1989. Oxford University Press, Oxford, UK.

World Bank. 1994. Lending for industrial technology: Lessons from six countries. Operations Evaluations Department Précis 70, Washington DC.

World Bank. 1995. Developing Industrial Technology: Lessons for Policy and Practice. Operations Evaluation Department Report No. 14983, Washington DC.

World Bank. 1998. World Development Report 1998/99: Knowledge for Development. Oxford University Press, Oxford UK. 
Table 1: Means of Variables.

\begin{tabular}{|c|c|c|c|c|}
\hline Variable & Measurement & Mean & Std. Dev. & Source \\
\hline R\&D Expenditures & Divided by GDP & 0.0127 & 0.0086 & UNESCO \\
\hline Per Capita GDP & 1000s of 1987 US Dollars & 8.2051 & 7.3977 & WDI \\
\hline Primary Enrollment Rate & & 101.8 & 8.4340 & $W D I$ \\
\hline Tertiary Enrollment Rate & & 28.0 & 15.9 & $W D I$ \\
\hline Risk of Expropriation & $\begin{array}{l}\text { Scaled between } 0-10 \text {. } \\
\text { High value means risk of expropriation is low. }\end{array}$ & 8.2382 & 1.8791 & $I C R G$ \\
\hline Rule of Law & $\begin{array}{l}\text { Scaled between } 0-6 \text {. } \\
\text { High value means rule of law is strong. }\end{array}$ & 4.4425 & 1.5395 & $I C R G$ \\
\hline $\begin{array}{l}\text { Claims on Private Sector by Central and } \\
\text { Deposit Money Banks }\end{array}$ & $\%$ of GDP & 0.5004 & 0.2993 & $I F S$ \\
\hline Incoming Foreign Direct Investment & $\%$ of GDP & 1.1020 & 1.7328 & $W D I$ \\
\hline Openness to Trade & $\%$ of GDP & 66.3 & 45.7 & $W D I$ \\
\hline Black Market Premium (Natural Log) & $\begin{array}{l}\text { (Difference between black market and official } \\
\text { exchange rates) divided by official rate }\end{array}$ & 0.1859 & 0.4610 & $I C A$ \\
\hline Government Expenditures & $\%$ of GDP & 15.7623 & 5.4922 & WDI \\
\hline Defense Expenditures & $\%$ of GDP & 3.0689 & 2.6335 & SIPRI \\
\hline
\end{tabular}

$\begin{array}{lll}\text { Note: } & \text { WDI } & \text { World Bank. World Development Indicators. World Bank, Washington DC. } \\ & \text { IFS } & \text { International Monetary Fund. International Financial Statistics. International Monetary Fund, Washington DC. } \\ & \text { SIPRI } & \text { SIPRI. SIPRI Yearbook. Oxford University Press, Oxford UK. } \\ \text { UNESCO } & \text { UNESCO. UNESO Statistical Yearbook. Bernan Press, Lanham MD. } \\ \text { ICRG } & \text { International Country Risk Guide (From Knack and Keefer, 1995) } \\ & \text { ICA } & \text { International Currency Analysis, Inc. World Currency Yearbook. International Currency Analysis, Inc, } \\ & \text { Brooklyn, NY }\end{array}$

Table 2: Sensitivity Analysis for middle and low-income countries

\begin{tabular}{|c|c|c|c|c|c|}
\hline Variable & & Point Est. & t-stat. & Other Variables & Summary \\
\hline \multirow{2}{*}{ Per Capita GDP } & High & 1.3300 & 5.03 & $\begin{array}{l}\text { Per Capita GDP }{ }^{2} \text {, Rule of Law, Openness } \\
\text { to Trade }\end{array}$ & \multirow{2}{*}{ Robust (5\%) } \\
\hline & Low & 0.3842 & 5.06 & $\begin{array}{l}\text { Tertiary Enroll, Rule of Law, Claims on } \\
\text { Private Sector }\end{array}$ & \\
\hline \multirow[t]{2}{*}{ Risk of Expropriation } & High & 0.1242 & 4.95 & $\begin{array}{l}\text { Per Capita GDP }{ }^{2} \text {, Tertiary Enroll, Claims } \\
\text { on Private Sect or, Openness to Trade }\end{array}$ & \multirow[t]{2}{*}{ Robust (5\%) } \\
\hline & Low & 0.0745 & 2.53 & Tertiary Enroll, Black Market Premium & \\
\hline \multirow{2}{*}{ Incoming FDI } & High & -0.0558 & -2.81 & $\begin{array}{l}\text { Per Capita GDP }{ }^{2} \text {, Rule of Law, Openness } \\
\text { to Trade, Black Market Premium }\end{array}$ & \multirow{2}{*}{ Robust (5\%) } \\
\hline & Low & -0.0913 & -5.95 & $\begin{array}{l}\text { Tertiary Enroll, Rule of Law, Claims on } \\
\text { Private Sector, Black market Premium }\end{array}$ & \\
\hline \multirow[t]{2}{*}{ Primary Enrollment Rate } & High & 0.0120 & 2.64 & $\begin{array}{l}\text { Per Capita GDP }{ }^{2} \text {, Tertiary Enroll, Rule of } \\
\text { Law, Claims on Private Sect or }\end{array}$ & \multirow[t]{2}{*}{ Fragile. } \\
\hline & Low & -0.0014 & -0.25 & Tertiary Enrollment Rate, Rule of Law & \\
\hline \multirow[t]{2}{*}{ Government Expenditures } & High & -0.0107 & -1.03 & $\begin{array}{l}\text { Per Capita GDP }{ }^{2} \text {, Rule of Law, Openness } \\
\text { to Trade, Black Market Premium }\end{array}$ & \multirow[t]{2}{*}{ Point Est. Negative } \\
\hline & Low & -0.0543 & -5.56 & Tertiary Enroll, Openness to Trade & \\
\hline \multirow[t]{2}{*}{ Defense Expenditures } & High & 0.1427 & 4.82 & $\begin{array}{l}\text { Tertiary Enroll, Rule of Law, Openness to } \\
\text { Trade }\end{array}$ & \multirow[t]{2}{*}{ Point Est. Positive } \\
\hline & Low & 0.0370 & 1.17 & Claims on Private Sector & \\
\hline
\end{tabular}


Table 3: Fixed Effects Regressions.

\begin{tabular}{|c|c|c|c|c|c|c|c|c|c|c|c|c|}
\hline & (1) & (2) & (3) & $(4)$ & $(5)$ & $(6)$ & $(7)$ & $(8)$ & (9) & $(10)$ & (11) & (12) \\
\hline Dependent Variables & \multicolumn{12}{|c|}{$\begin{array}{c}\text { Research and Development Expenditures } \\
\text { (as \% of GDP) }\end{array}$} \\
\hline Sample & \multicolumn{6}{|c|}{ All Middle and Low Income Countries } & \multicolumn{2}{|c|}{ All Countries } & \multicolumn{2}{|c|}{$\begin{array}{l}\text { Middle Income } \\
\text { Countries }\end{array}$} & \multicolumn{2}{|c|}{$\begin{array}{c}\text { Middle and Low } \\
\text { Income (except } \\
\text { Transition) } \\
\end{array}$} \\
\hline Number of Observations & 102 & 123 & 102 & 123 & 102 & 123 & 225 & 252 & 90 & 105 & 75 & 86 \\
\hline Number of Countri & 26 & 28 & 26 & 28 & 26 & 28 & 50 & 52 & 22 & 24 & 19 & 20 \\
\hline Degrees of Freedor & 52 & 76 & 52 & 77 & 52 & 52 & 152 & 182 & 45 & 63 & 33 & 48 \\
\hline Per Capita Income & & & & & & & & & & & & \\
\hline $\begin{array}{l}\text { Per Capita GDP } \\
\text { (1000s of } 1987 \text { U.S. dollars) }\end{array}$ & $\begin{array}{l}0.6615^{\star *} \\
(3.37)\end{array}$ & $\begin{array}{c}0.5658^{* *} \\
(8.17)\end{array}$ & $\begin{array}{c}0.6747^{* *} \\
(3.42)\end{array}$ & $\begin{array}{c}0.5652^{* *} \\
(8.01)\end{array}$ & $\begin{array}{l}0.6189^{* *} \\
(2.70)\end{array}$ & $\begin{array}{l}0.6390^{\star *} \\
(10.08)\end{array}$ & $\begin{array}{l}0.3401^{* *} \\
(5.86)\end{array}$ & $\begin{array}{l}0.1040^{* *} \\
(3.35)\end{array}$ & $\begin{array}{l}0.6923^{\star *} \\
(3.68)\end{array}$ & $\begin{array}{l}0.5482^{\star *} \\
(6.98)\end{array}$ & $\begin{array}{l}0.3261^{* *} \\
(2.09)\end{array}$ & $\begin{array}{l}0.3241^{\star *} \\
(6.17)\end{array}$ \\
\hline $\begin{array}{l}\text { Per Capita GDP Squared } \\
\text { Human Capital }\end{array}$ & $\begin{array}{c}-0.0388 \\
(-1.51)\end{array}$ & ---- & $\begin{array}{c}-0.0387 \\
(-1.48)\end{array}$ & ---- & $\begin{array}{c}-0.0188 \\
(-0.66)\end{array}$ & --- & $\begin{array}{l}-0.0077^{\star *} \\
(-5.70)\end{array}$ & --- & $\begin{array}{c}-0.0461^{*} \\
(-1.84)\end{array}$ & --- & $\begin{array}{l}-0.0102 \\
(-0.51)\end{array}$ & --- \\
\hline Primary Enrollment Rate & $\begin{array}{l}0.0113^{* *} \\
(2.61)\end{array}$ & $\begin{array}{c}0.0055 \\
(1.12)\end{array}$ & $\begin{array}{c}0.0104^{* *} \\
(2.36)\end{array}$ & $\begin{array}{c}0.0056 \\
(1.12)\end{array}$ & $\begin{array}{c}0.0025 \\
(0.55)\end{array}$ & $\begin{array}{r}0.0041 \\
(0.82)\end{array}$ & $\begin{array}{c}0.0003 \\
(0.11)\end{array}$ & $\begin{array}{c}0.0054 \\
(1.31)\end{array}$ & $\begin{array}{l}0.0183^{* *} \\
(3.28)\end{array}$ & $\begin{array}{c}0.0071 \\
(1.20)\end{array}$ & $\begin{array}{l}0.0096^{* *} \\
(3.06)\end{array}$ & $\begin{array}{c}0.0067^{* *} \\
(2.41)\end{array}$ \\
\hline Tertiary Enrollment Rate & $\begin{array}{c}-0.0017 \\
(-0.24)\end{array}$ & --- & $\begin{array}{c}-0.0032 \\
(-0.44)\end{array}$ & --- & $\begin{array}{c}0.0012 \\
(0.16)\end{array}$ & --- & $\begin{array}{l}0.0075^{* *} \\
(3.13)\end{array}$ & --- & $\begin{array}{c}-0.0052 \\
(-0.69)\end{array}$ & ---- & $\begin{array}{c}0.0027 \\
(0.44)\end{array}$ & --- \\
\hline Institutional Qu & & & & & & & & & & & & \\
\hline $\begin{array}{l}\text { Risk of Expropriation (lagged) } \\
\text { [higher value means lower risk] }\end{array}$ & $\begin{array}{l}0.1186^{* *} \\
(5.12)\end{array}$ & $\begin{array}{c}0.0717^{* *} \\
(2.92)\end{array}$ & $\begin{array}{l}0.1203^{* *} \\
(5.06)\end{array}$ & $\begin{array}{c}0.0732^{* *} \\
(2.60)\end{array}$ & --- & --- & $\begin{array}{l}0.0382^{*} \\
(1.91)\end{array}$ & $\begin{array}{l}0.0672^{* *} \\
(3.01)\end{array}$ & $\begin{array}{c}0.1421^{* *} \\
(4.55)\end{array}$ & $\begin{array}{l}0.0918^{* *} \\
(2.41)\end{array}$ & $\begin{array}{l}0.0295^{\star} \\
(1.68)\end{array}$ & $\begin{array}{l}0.0277^{* *} \\
(2.08)\end{array}$ \\
\hline $\begin{array}{l}\text { Rule of Law (lagged) } \\
\text { [higher value means better institutions] } \\
\text { Capital Market Development }\end{array}$ & $\begin{array}{c}0.0452^{*} \\
(1.72)\end{array}$ & $\begin{array}{c}0.0104 \\
(0.20)\end{array}$ & --- & --- & $\begin{array}{l}0.0549^{*} \\
(1.76)\end{array}$ & $\begin{array}{c}0.0326 \\
(0.60)\end{array}$ & --- & --- & --- & --- & --- & --- \\
\hline $\begin{array}{l}\text { Claims on Private Sector by Central and } \\
\text { Deposit Money Banks (lagged) [\% of GDP] } \\
\text { Openness }\end{array}$ & $\begin{array}{l}0.0011 \\
(0.56)\end{array}$ & ---- & $\begin{array}{l}0.0012 \\
(0.63)\end{array}$ & ---- & $\begin{array}{c}0.0016 \\
(0.78)\end{array}$ & ---- & $\begin{array}{l}0.0022^{\star *} \\
(2.11)\end{array}$ & ---- & $\begin{array}{l}-0.0011 \\
(-0.54)\end{array}$ & ---- & $\begin{array}{l}0.0002 \\
(0.17)\end{array}$ & ---- \\
\hline $\begin{array}{l}\text { Foreign Direct Investment (lagged) } \\
\text { [\% of GDP] }\end{array}$ & $\begin{array}{c}-0.0823^{\star *} \\
(-5.69)\end{array}$ & $\begin{array}{l}-0.0740^{* *} \\
(-4.04)\end{array}$ & $\begin{array}{c}-0.0779^{\star *} \\
(-5.28)\end{array}$ & $\begin{array}{c}-0.0731^{* \star} \\
(-4.19)\end{array}$ & $\begin{array}{l}-0.0788^{* *} \\
(-4.58)\end{array}$ & $\begin{array}{c}-0.0664^{* \star} \\
(-3.50)\end{array}$ & $\begin{array}{c}-0.0923^{* *} \\
(-6.18)\end{array}$ & $\begin{array}{c}-0.0622^{* *} \\
(-2.99)\end{array}$ & $\begin{array}{c}-0.1039^{* *} \\
(-5.49)\end{array}$ & $\begin{array}{c}-0.0984^{* *} \\
(-5.71)\end{array}$ & $\begin{array}{c}-0.0288^{* *} \\
(-2.64)\end{array}$ & $\begin{array}{c}-0.0289 * * \\
(-2.49)\end{array}$ \\
\hline $\begin{array}{l}\text { Openness to Trade (lagged) } \\
{[\% \text { of GDP] }}\end{array}$ & $\begin{array}{c}0.0029 \\
(1.25)\end{array}$ & ---- & $\begin{array}{l}0.0033 \\
(1.38)\end{array}$ & ---- & $\begin{array}{c}0.0018 \\
(0.67)\end{array}$ & ---- & $\begin{array}{c}0.0016 \\
(0.71)\end{array}$ & --- & $\begin{array}{l}0.0024 \\
(1.14)\end{array}$ & --- & $\begin{array}{c}-0.0038^{*} \\
(-1.77)\end{array}$ & --- \\
\hline $\begin{array}{l}\text { Black Market Premium (lagged) } \\
\text { [Natural Log] } \\
\text { Government Expenditures }\end{array}$ & $\begin{array}{c}-0.1280 \\
(-1.23)\end{array}$ & --- & $\begin{array}{c}-0.1224 \\
(-1.15)\end{array}$ & --- & $\begin{array}{l}-0.1976^{*} \\
(-1.68)\end{array}$ & --- & $\begin{array}{l}-0.1589 \\
(-1.27)\end{array}$ & ---- & $\begin{array}{l}0.0441 \\
(0.31)\end{array}$ & ---- & $\begin{array}{c}-0.1593^{* *} \\
(-2.21)\end{array}$ & ---- \\
\hline $\begin{array}{l}\text { Government Expenditures (lagged) } \\
{[\% \text { of GDP] }}\end{array}$ & $\begin{array}{l}-0.0227^{*} \\
(-1.86)\end{array}$ & $\begin{array}{c}-0.0407^{* *} \\
(-4.61)\end{array}$ & $\begin{array}{l}-0.0221^{*} \\
(-1.79)\end{array}$ & $\begin{array}{c}-0.0404^{* *} \\
(-4.44)\end{array}$ & $\begin{array}{c}-0.0185 \\
(-1.47)\end{array}$ & $\begin{array}{c}-0.0421^{* *} \\
(-4.39)\end{array}$ & $\begin{array}{c}0.0023 \\
(0.21)\end{array}$ & $\begin{array}{l}-0.0501^{* *} \\
(-4.56)\end{array}$ & $\begin{array}{c}-0.0242^{*} \\
(-1.85)\end{array}$ & $\begin{array}{c}-0.0356^{* *} \\
(-3.67)\end{array}$ & $\begin{array}{c}-0.0061 \\
(-0.62)\end{array}$ & $\begin{array}{l}0.0035 \\
(0.42)\end{array}$ \\
\hline $\begin{array}{l}\text { Defense Expenditures (lagged) } \\
\text { [\% of GDP] }\end{array}$ & $\begin{array}{l}0.0633^{* *} \\
(1.98)\end{array}$ & $\begin{array}{c}0.1216^{* *} \\
(3.89)\end{array}$ & $\begin{array}{l}0.0642^{* *} \\
(1.97)\end{array}$ & $\begin{array}{c}0.1204^{* *} \\
(3.68)\end{array}$ & $\begin{array}{c}0.0537 \\
(1.51)\end{array}$ & $\begin{array}{c}0.1155^{\star *} \\
(3.38)\end{array}$ & $\begin{array}{l}0.0737^{* *} \\
(3.89)\end{array}$ & $\begin{array}{c}0.1019^{* *} \\
(4.22)\end{array}$ & $\begin{array}{c}0.0733^{* *} \\
(2.35)\end{array}$ & $\begin{array}{c}0.1234^{* *} \\
(4.36)\end{array}$ & $\begin{array}{c}-0.0411 \\
(-1.26)\end{array}$ & $\begin{array}{c}-0.0222 \\
(-0.81)\end{array}$ \\
\hline R-Squared & 0.979 & 0.960 & 0.978 & 0.960 & 0.972 & 0.952 & 0.979 & 0.956 & 0.982 & 0.965 & 0.979 & 0.972 \\
\hline
\end{tabular}

* Significant at $10 \%$ level $\quad * *$ Significant at $5 \%$ level

Note: All regressions include both country and time dummies. T-statistics are in parentheses. 